\title{
Proteolysis of insulin-like growth factor binding proteins (IGFBPs) by calpain
}

\author{
Madhumita Ghosh', Sreejesh Shanker', Igor \\ Siwanowicz', Karlheinz Mann', Werner \\ Machleidt ${ }^{2}$ and Tad A. Holak ${ }^{1, *}$
}

\author{
${ }^{1}$ Max Planck Institute for Biochemistry, D-82152 \\ Martinsried, Germany \\ ${ }^{2}$ Adolf Butenandt Institute of Physiological Chemistry, \\ University of Munich, Schillerstr. 42, D-80336 Munich, \\ Germany \\ ${ }^{*}$ Corresponding author \\ e-mail: holak@biochem.mpg.de
}

\begin{abstract}
Calpains are non-lysosomal, $\mathrm{Ca}^{2+}$-dependent cysteine proteases, which are ubiquitously distributed across cell types and vertebrate species. The rules that govern calpain specificity have not yet been determined. To elucidate the cleavage pattern of calpains, we carried out calpain-induced proteolytic studies on the insulin-like growth factor binding proteins IGFBP-4 and -5 . Proteolysis of IGFBPs is well characterized in numerous reports. Our results show that calpain cleavage sites are in the non-conserved unstructured regions of the IGFBPs. Compilation of the calpain-induced proteolytic cleavage sites in several proteins reported in the literature, together with our present study, has not revealed clear preferences for amino acid sequences. We therefore conclude that calpains seem not to recognize amino acid sequences, but instead cleave with low sequence specificity at unstructured or solvent-exposed fragments that connect folded, stable domains of target proteins.
\end{abstract}

Keywords: calpain; $\mathrm{Ca}^{2+}$-dependent cysteine protease; calpastatin; insulin-like growth factor binding protein.

\section{Introduction}

Calpains are a large family of $\mathrm{Ca}^{2+}$-dependent cysteine proteases ubiquitously expressed in mammalian cells. The two major mammalian calpains are designated $\mu$-calpain and $\mathrm{m}$-calpain based on their in vitro activation, which requires micromolar and millimolar concentrations of $\mathrm{Ca}^{2+}$, respectively (Goll et al., 2003). The two enzymes appear to be very similar in many biochemical properties and their structures also show a similar folding pattern (Pal et al., 2003) but significant differences are observed in the catalytic triad of residues of these two isoforms (Strobl et al., 2000). Calpains are heterodimers composed of a large catalytic subunit of $80 \mathrm{kDa}$ (containing domains $\mathrm{I}-\mathrm{IV}$ ) and a small $28-\mathrm{kDa}$ regulatory subunit (composed of domains $\mathrm{V}$ and $\mathrm{VI}$ ). The small subunit is identical in both isoforms, but the large subunits are generated by two different genes (Dear and
Boehm, 2001; Sorimachi and Suzuki, 2001; Goll et al., 2003). Activation of the protease core of $\mu$-calpain requires cooperative binding of two $\mathrm{Ca}^{2+}$ atoms at two non-EF-hand sites (Khorchid and Ikura, 2002; Moldoveanu et al., 2002, 2004). Substantial evidence indicates that calpains play a crucial role in a diverse spectrum of cellular responses, which include cell differentiation, apoptosis, cytoskeletal remodeling, signal transduction and, most recently identified, cell adhesion and motility (Croall and Demartino, 1991; Sato and Kawashima, 2001; Glading et al., 2002; Goll et al., 2003). Although definitive physiological roles are not yet established, dysregulated $\mathrm{Ca}^{2+}$ levels result in aberrant proteolysis by calpains, which contributes to tissue damage in heart and brain ischemia, cerebral infarction, acute neurological disorders such as stroke and, more recently identified, to Alzheimer's disease (Huang and Wang, 2001). Calpains have been also identified as a susceptible gene in type 2 diabetes (Kuwaki et al., 1989). Calpains are generally believed to exist and function in the cytoplasm, but a few studies have reported the existence of $\mathrm{m}$-calpain in the extracellular spaces of various tissues (Glading et al., 2001; Nishihara et al., 2001). Immunolocalization studies have shown extracellular localization of calpains in diseased states (Kumamoto et al., 1992).

The rules that govern calpain specificity have not yet been determined. In this paper we attempt to characterize calpain preferred cleavage positions in the insulin-like growth factor binding proteins (IGFBPs). We have chosen to use these proteins for our calpain study for two reasons. First, proteolysis of IGFBPs is extensively characterized by numerous reports; this is because limited proteolysis of IGFBPs is the major mechanism for the release of IGFs from IGFBP/IGF complexes, generating IGFBP fragments with reduced affinity for IGFs (Binoux et al., 1999; Khandwala et al., 2000). This thereby increases the concentration of IGFs at the cell surface and allows IGFs to bind and activate the IGF receptor (Bunn and Fowlkes, 2003). Secondly, IGFBPs are structurally well characterized; they are composed of globular domains linked by large flexible fragments, thus providing model proteins that contain diverse structural elements (Kalus et al., 1998).

IGFBPs are also active in the cellular environment, as they may regulate cells by IGF-independent mechanisms (Oh and Rosenfeld, 1999; Baxter, 2000; Firth and Baxter, 2002). The effects of intracellular IGFBPs are complex, however, with both stimulatory and inhibitory actions. In addition, the regulation of intracellular IGFBPs by proteases influences the IGFBP extracellular concentration. Proteolytically cleaved fragments of the same IGFBP protein may display different cellular localizations. Several studies have identified IGFBP-3 in cell nuclei or directly demonstrated its nuclear transport by an importin $\beta$ mediated mechanism (Jaques et al., 1997; Wraight et al., 
1998). Competition studies suggested that IGFBP-5 uses the same nuclear transport system as IGFBP-3 (Schedlich et al., 1998). We have studied the calpain-induced proteolysis of two members of the IGFBP family (IGFBP4 and IGFBP-5) in this paper. We expect, however, that calpain proteolysis will be very similar for other IGFPBPs because of the amino acid sequence and structural similarities of these proteins.

\section{Results}

The sodium dodecyl sulfate-polyacrylamide gel electrophoresis (SDS-PAGE) analysis of the in vitro assay clearly showed that there were calpain cleavage sites in both IGFBP-4 and IGFBP-5 and both proteins were rapidly cleaved into smaller fragments (Figure 1A, B). For $1000 \mathrm{~nm}$ IGFBPs, as little as $20 \mathrm{~nm} \mu$-calpain was sufficient to induce cleavage and a further increase in the protease concentration up to $250 \mathrm{~nm}$ did not result in any change in the cleavage pattern. In addition, there was no change observed with increasing time: cleavage patterns obtained within the first 30 min were the same as those obtained after $4 \mathrm{~h}$. This was expected, as calpain is an autolytic enzyme (Tompa and Friedrich, 2000; Li et al., 2002) and autolyses within the first $30 \mathrm{~min}$, which results in protease activation, but an increased time interval does not result in any extra cleavage sites, which shows that calpain-mediated proteolysis is limited. The IGFBP protein stability assays showed that the proteins were stable and did not degrade at room temperature for up to $48 \mathrm{~h}$, as shown in Figure 2. Figure 3A shows the Western blot analysis of IGFBP cleavage products after digestion with $20 \mathrm{nM} \mu$-calpain. Figure $3 \mathrm{~B}$ shows the results of the inhibitory assay of the endogenous protein inhibitor of calpains, calpastatin (Goll et al., 2003). Calpastatin efficiently blocked the cleavage of both IGFBP-4 and IGFBP-5, as no cleavage fragments of the proteins were observed. Domain I of calpastatin was chosen for the experiment as it inhibits $\mu$ - or $\mathrm{m}$-calpain to a greater extent compared to other domains (Goll et al., 2003). This result clearly indicates that the cleavage pattern observed was entirely due to calpain and not to any other contaminating protease. In addition, no cleavage was observed in the absence of calcium, in agreement with the fact that calcium is necessary to induce the autocatalytic activity of calpain.

Characterization of the cleavage sites in IGFBPs was accomplished by subjecting proteolytic products to $\mathrm{NH}_{2}-$ terminal sequencing by Edman degradation. The amino acid sequences obtained for IGFBP-4 were: GSSHH, $A_{3} I H C, M_{73} H G Q G, A_{87} I Q E S L, A_{123} K I R$, and $G_{139} A P R$. Exact molecular weights of the isolated fragments were determined by matrix-assisted laser desorption/ionization-mass spectrometry (MALDI-MS). Similarly, for IGFBP-5, the amino acid sequences obtained from the $\mathrm{N}$-terminal sequencing were: $\mathrm{S}_{3} \mathrm{FVH}, \mathrm{C}_{8} \mathrm{EPCD}, \mathrm{Q}_{142} \mathrm{SKFV}$, and $A_{153} \mathrm{HPRI}$. The results of the fragments generated from polyvinylidene fluoride (PVDF) analysis and reversephase HPLC were mapped onto the IGFBP-4 and IGFBP-5 sequences and all the theoretically possible cleavage fragments for both IGFBPs were simulated.
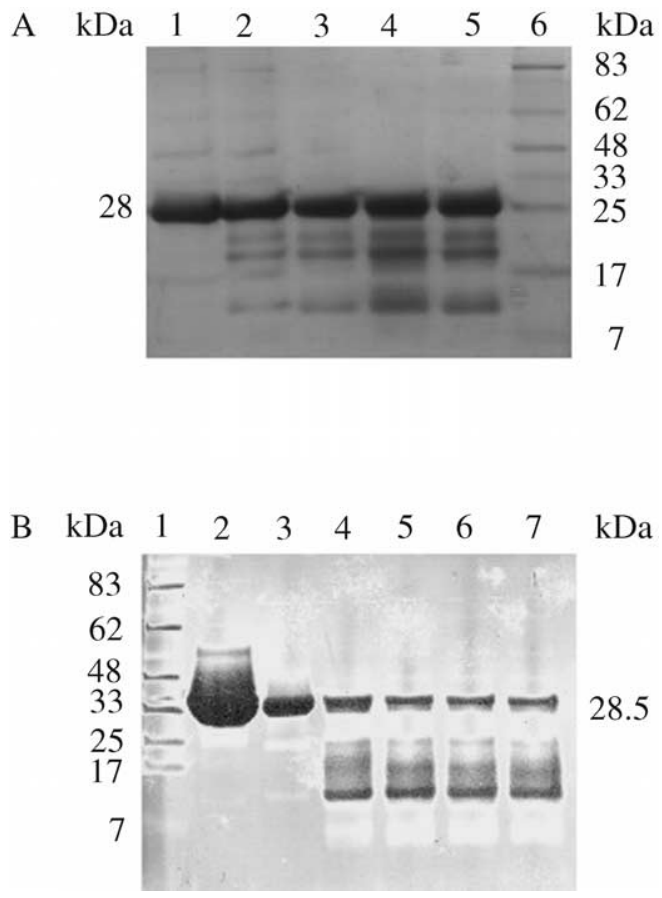

Figure 1 SDS-PAGE analysis of fragments generated by calpain cleavage.

(A) SDS-PAGE analysis of IGFBP-4 proteolysis by $\mu$-calpain. Lane 1 contains aliquots of the undigested protein as the control. Lanes 2-5 contain aliquots of the digestion reaction of IGFBP-4 cleavage at different calpain concentrations $(20,50$, 100 and $250 \mathrm{~nm}$ ) in the calpain assay buffer. Lane 6 shows the prestained molecular mass protein marker $(\mathrm{kDa})$.

(B) SDS-PAGE analysis of IGFBP- 5 digested by $\mu$-calpain. Lane 1 shows the prestained marker. Lane 2 contains the undigested IGFBP-5 protein. Lanes 3-7 show IGFBP-5 cleavage at different time intervals of $0 \mathrm{~min}, 30 \mathrm{~min}, 1 \mathrm{~h}, 2 \mathrm{~h}$, and $4 \mathrm{~h}$, respectively, at a constant calpain concentration of $20 \mathrm{nM}$ in the calpain reaction buffer. IGFBP-4 is a $28-\mathrm{kD}$ a protein and IGFBP- 5 is $28.5 \mathrm{kDa}$ in molecular mass.

Mass spectrometry showed that fragments of the following sizes were generated for IGFBP-4: 14.75, 13.10, $11.01,10.90,4.10$, and $2.45 \mathrm{kDa}$ (Figure 4A). For IGFBP5 , fragments of $15.69,16.81,12.70$, and $11.60 \mathrm{kDa}$ were obtained (Figure 4B). These mass spectrometry results, together with the results from $\mathrm{N}$-terminal sequencing, identified cleavage sites at amino-acid positions 2, 86, 122, and 138 in IGFBP-4 (Figure 5). Hence, in IGFBP-4 calpain appears to act on the bond between Glu 2 and Ala 3, generating a fragment of approximately $2.45 \mathrm{kDa}$,

M $0 \mathrm{~h} \quad 6 \mathrm{~h} \quad 12 \mathrm{~h} \quad 24 \mathrm{~h} \quad 36 \mathrm{~h} \quad 48 \mathrm{~h} \quad 60 \mathrm{~h} \quad 72 \mathrm{~h} \quad 84 \mathrm{~h}$

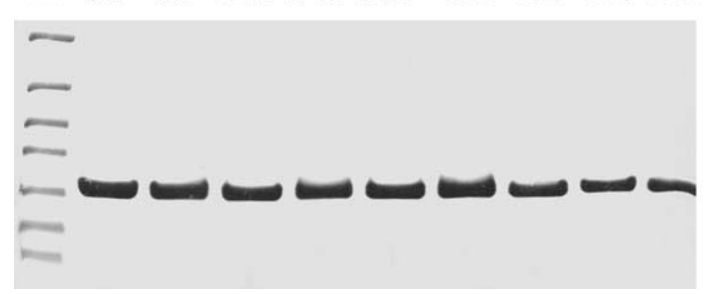

Figure 2 IGFBP stability gel showing the protein at different time intervals.

Lane $\mathrm{M}$ shows the prestained molecular mass protein marker $(\mathrm{kDa})$ and the remaining lanes contain aliquots of the protein in the calpain assay buffer at different time intervals. The protein remains stable even after 3 days. 
A

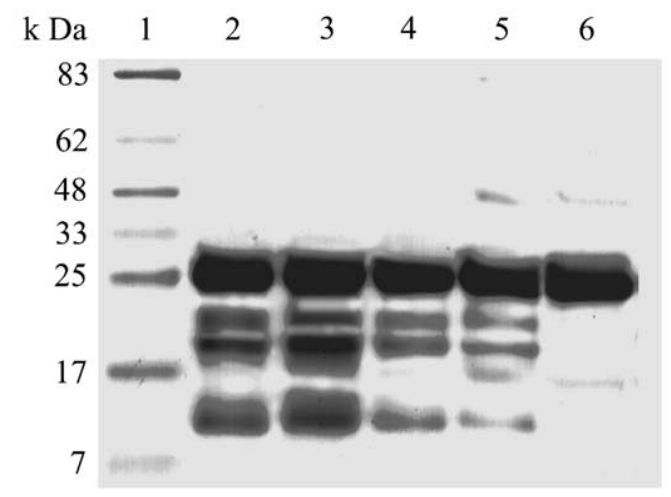

B

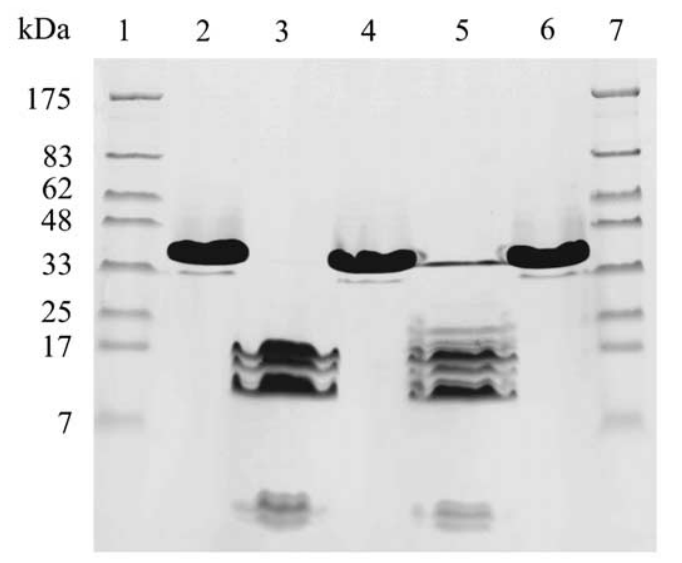

Figure 3 Western blot analysis and calpastatin inhibitory assay. (A) Western blot of IGFBP fragments generated by $\mu$-calpain protease cleavage. IGFBP digested with calpain was resolved by SDS-PAGE and transferred onto a nitrocellulose membrane. Cleaved fragments of IGFBP were detected by immunoassaying with IGFBP polyclonal antibodies. Lane 1 shows the prestained marker. Lanes 2-5 highlight the cleavage products of IGFBP. Lane 6 consists of the undigested IGFBP protein as control.

(B) Calpastatin inhibitory and $\mathrm{Ca}^{2+}$-dependent protease assay. Lanes 1 and 7 show the molecular weight protein marker. Lane 2 shows IGFBP protein incubated with the protease, $\mu$-calpain and calpastatin in the absence of $\mathrm{Ca}^{2+}$, where no cleavage occurs. Lanes 3 and 5 contain aliquots of IGFBP-4 and IGFBP5 , respectively, digested with $20 \mathrm{nM} \mu$-calpain in the absence of calpastatin and supplemented with $1 \mathrm{mM} \mathrm{Ca}^{2+}$. Lanes 4 and 6 show the inhibition of the IGFBP- 4 and -5 cleavage by $\mu$-calpain in the presence of calpastatin at molar concentrations of $1: 1$ with calpain.

which corresponds to the $20 \mathrm{His} / \mathrm{T} 7$-tag, residues along with the first three residues of the amino terminus of the protein. The other three major cleavage sites were found in the weakly conserved regions of the protein at Glu 86 and Ala 87, generating fragments of approximately 11.01 and $16.0 \mathrm{kDa}$. There was another small fragment of $4.10 \mathrm{kDa}$ observed in mass spectrometry instead of the large $16.0-\mathrm{kDa}$ fragment. This discrepancy arose because this larger fragment was further cleaved at another major internal cleavage site, Phe 122 and Ala 123 , which generated fragments of 4.10 and $13.10 \mathrm{kDa}$. The last major site was the bond between Asp 138 and Gly 139 , which resulted in a fragment of $10.90 \mathrm{kDa}$. The $\mathrm{NH}_{2}$-terminal sequencing of IGFBP-4 yielded another weak cleavage site at the bond between Leu 72 and Met 73 , which corresponds to the $\mathrm{N}$-terminal region of the protein, but mass spectroscopy did not show any such fragment with the corresponding molecular weight. Hence, this site was not considered as a major cleavage site.

In IGFBP-5, we identified cleavage sites at residues 2, 141, and 152, as shown in Figures 4B and 5. Three major cleavage sites were observed: the first site is between the residues Gly 2 and Ser 3 located at the very beginning of the protein at the amino-terminus. $\mathrm{NH}_{2}$-terminal sequencing of IGFBP-5 also showed another very close site between His 7 and Cys 8, but this was probably due to degradation of the $\mathrm{N}$-terminus following initial cleavage, as no corresponding fragment was evident in the

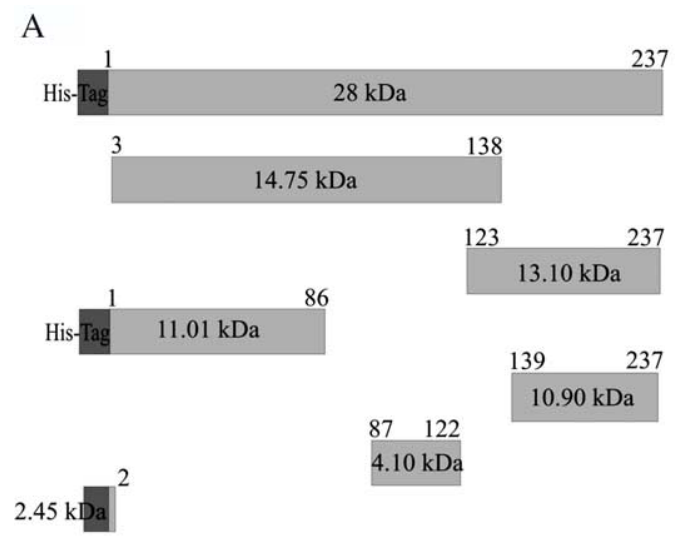

B

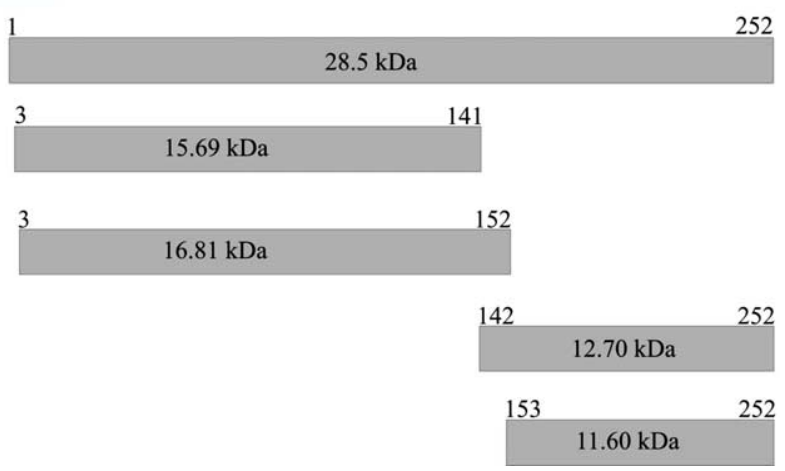

Figure 4 Schematic representation of the fragments generated by calpain cleavage.

Fragments for IGFBP-4 (A) and IGFBP-5 (B).

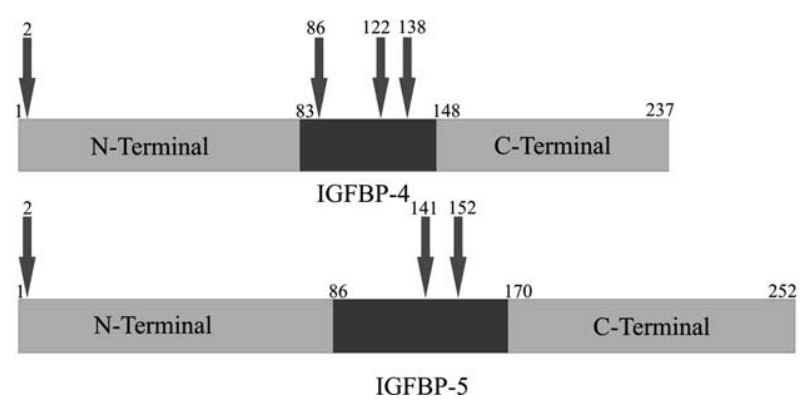

Figure 5 Summary of the location of the principal calpain cleavage sites in IGFBP-4 and IGFBP-5. 

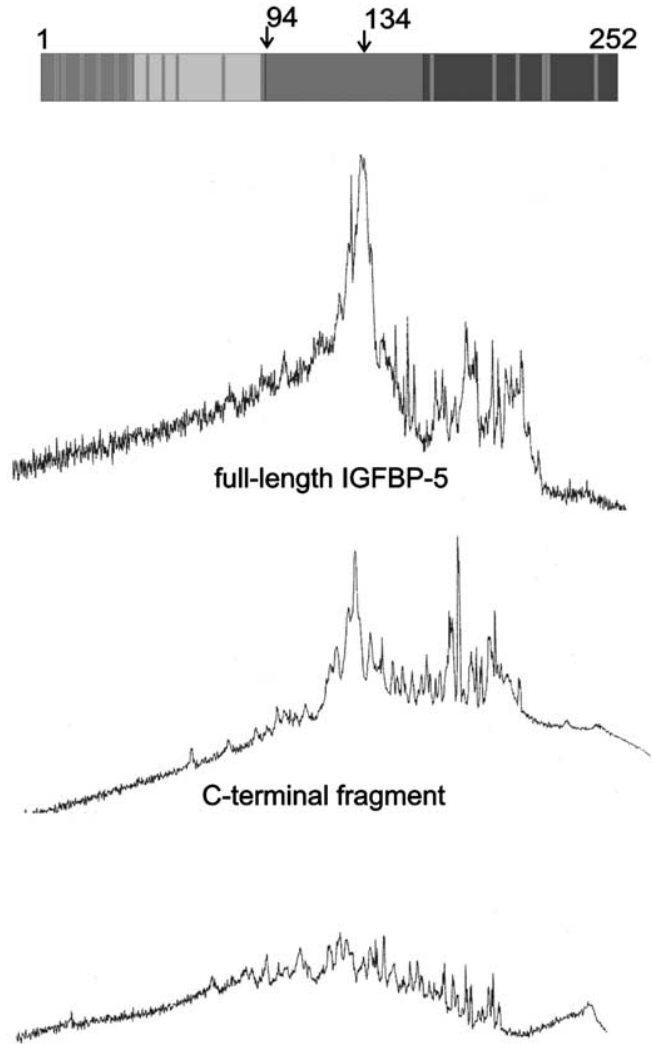

$\mathrm{N}$-terminal $10 \mathrm{kDa}$ fragment

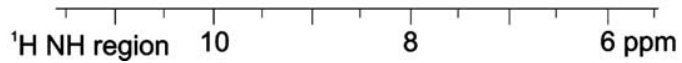

Figure 6 The amide region of one-dimensional NMR spectra of the recombinant human IGFBP-5.

The upper, middle and lower panels show the full-length protein, a C-terminal fragment of 112 (residues 135-246) and an N-terminal fragment of 94 residues, respectively. The fragments were created by limited proteolysis with endoproteinase Asp-N. A schematic domain structure of IGFBP-5 consists of the N-terminal domain (light gray), a central domain (gray) and the Cdomain (dark gray). Sticks mark cysteines.

mass spectra. The other two cleavage sites are located in the weakly conserved domain of the protein, as in IGFBP-4, but not at the same residues. The first, located between Thr 141 and Gln 142, results in fragments of 15.69 and $12.70 \mathrm{kDa}$, and the second, between Thr 152 and Ala 153, generated fragments of 16.81 and $11.61 \mathrm{kDa}$.

Figure 6 shows one-dimensional ${ }^{1} \mathrm{H}$ NMR spectra of IGFBP-5. Inspection of such spectra yields semi-quantitative information on the extent of folding in proteins or their domains (Rehm et al., 2002). The upper panel shows the spectrum of the full-length IGFBP-5; this spectrum exhibits a large peak at $8.3 \mathrm{ppm}$ and some signals downfield (i.e., at higher ppm values) close to the noise level. The appearance of intensities at chemical shifts near $\sim 8.3 \mathrm{ppm}$ is an indicator of a disordered protein, as this is a region characteristic of backbone amides in a random coil configuration (Weber et al., 2000; Rehm et al., 2002). On the other hand, large signal dispersion beyond $8.3 \mathrm{ppm}$ proves a protein to be folded. Due to the different chemical environment and thus the varying shielding effects, the resonances of single protons will be distributed over a wide range of frequencies. A typical intensity pattern of a folded protein is shown in the lower panel, which shows the spectrum of the N-terminal fragment of IGFBP-5. The spectrum of the C-terminal fragment indicates that there are also some unstructured regions located in the $\mathrm{C}$-terminal fragment (Figure 6, middle). Based on these spectra, we can conclude that the central variable domain of IGFBP-5 is in a random coil conformation. Nearly identical estimates were obtained from NMR for IGFBP-3 and IGFBP-4 (data not shown).

\section{Discussion}

The IGFBP family comprises six proteins (IGFBP-1-6) that bind to IGFs with high affinity, and a group of IGFBPrelated proteins (IGFBP-rP 1-9), which show lower affinity for IGFs (Khandwala et al., 2000; Clemmons, 2001). IGFBPs-1-6 share a high degree of similarity in their primary protein structure (identities approx. 30-40\%), with highest conservation at the $\mathrm{N}$ - and $\mathrm{C}$-terminal regions (Figures 6 and 7), which participate in binding to IGFs (Baxter, 2000; Payet et al., 2003; Shand et al., 2003). The structure of the N-terminal domain of IGFBP-5 discloses a rigid, globular fold that consists of a centrally located three-stranded antiparallel $\beta$-sheet (Zeslawski et al., 2001). This is in contrast to the central, weakly conserved domain in IGFBPs, for which the NMR spectra presented here indicate a highly flexible, disordered conformation (Figure 6). This domain is also the site of proteolytic activity in IGFBPs (Figure 5). Our data indicate that there are four major calpain cleavage sites in IGFBP-4 and three in IGFBP-5 (Figure 5) all located in this region of the protein, except for the first cleavage sites in the $\mathrm{N}$-terminal domain of both the proteins. Comparison of the cleavage pattern of IGFBP-5 with endoproteinase Asp-N reveals that Asp- $\mathrm{N}$ cleaves in a generally similar manner to calpain (i.e., in the central domain of the protein); however, the specific bonds are different (Kalus et al., 1998).

Figure 7 and Table 1 show locations of the cleavage sites on IGFBPs found in the present study and those compiled from the literature for other proteases. All IGFBPs, except IGFBP-6, are highly sensitive to proteolysis (the resistance of IGFBP-6 may be due to the absence of hydrophobic residues, such as tyrosine, tryptophan and phenylalanine, a very small variable domain and a low number of basic amino acid residues). Generally, for all IGFBPs two-three major proteolytic cleavage sites always occur at the beginning and towards the end of the variable domain (Figure 7). Calpain follows this rule too. Although the $\mathrm{N}$ - and $\mathrm{C}$-terminal domains of IGFBPs are resistant to proteolytic attack, degradation of the C-terminal regions has been observed for IGFBP-3 (for plasmin, PSA, cathepsin D, and thrombin) and IGFBP-5 (thrombin) in in vitro studies. Figure 7 also includes our in vitro proteolysis of the recombinant human IGFBP-5 (residues 158-247) with thrombin. This fragment shows two extra cleavage sites compared to proteolysis of a full-length IGFPB-5 at physiological concentrations of thrombin (Zheng et al., 1998). A corresponding C-terminal region of IGFBP-4 (residues 


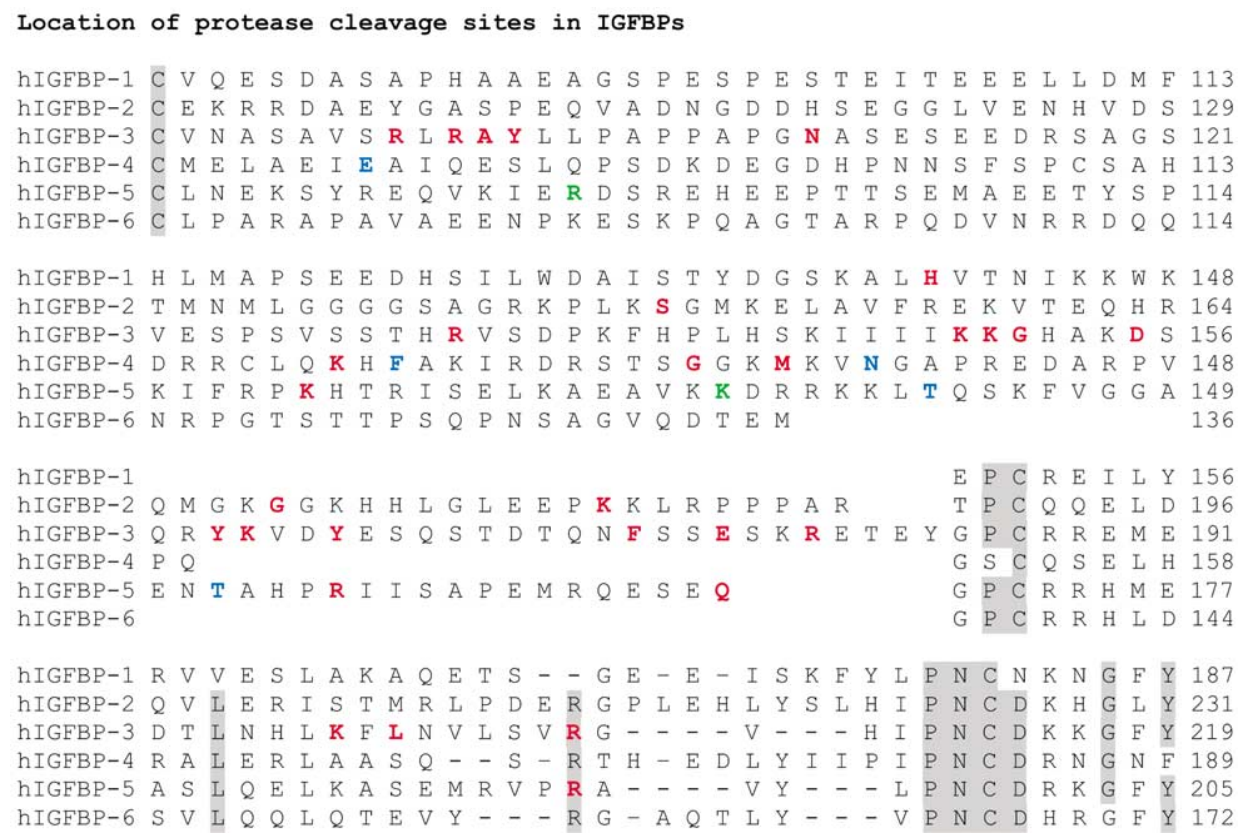

Figure 7 Sequence alignment of all the IGFBP non-conserved regions.

Grey, conserved amino acids; red, protease cleavage sites reported in the literature to date (see Table 1); blue, amino acids after which calpain cleaves; green, amino acids after which endoproteinase Asp-N cleaves.

171-252) was completely resistant to thrombin proteolysis in our experiments (data not shown).

Since IGFBP-3 and IGFBP-5 show structural similarities and both are synthesized by cell types derived from the mesenchyma, calpain is expected to cleave IGFBP3 in the same fashion as it cleaves IGFBP-5. There is evidence that a calpain-like cysteine protease is a key regulatory component required for passage through the $\mathrm{G}_{1}$ phase of the cell cycle in eukaryotes (Mellgren, 1997). As IGFBP-3 can traverse into the nucleus, calpain might also regulate the IGF-independent functions of IGFBP-3 (Baxter, 2000).
There are a limited number of reports on the subsite specificity of calpains and these have been reviewed by Croall and Demartino (1991) and more recently by Goll et al. (2003). In general, the literature data indicate that the calpains cleave target proteins at a limited number of sites and produce large polypeptide fragments rather than small peptides (Sasaki et al., 1984). Early studies suggested that the calpains preferentially cleaved peptide bonds with a Leu or a Val residue in the $\mathrm{P}_{2}$ position. More complete data, however, indicated that subsite specificity of the calpains is controlled by the conformation of the polypeptide chain and not by amino acid

Table 1 Proteolytic cleavage sites in IGFBPs.

\begin{tabular}{|c|c|c|c|}
\hline & $\begin{array}{l}\text { Protease } \\
\text { (source) }\end{array}$ & $\begin{array}{l}\text { Cleavage sites } \\
\text { (P1 residue) }\end{array}$ & Reference \\
\hline IGFBP-1 & Stromelysin-3 & 140 & Manes et al., 1997 \\
\hline \multirow[t]{2}{*}{ IGFBP-2 } & Fetal rat liver cell line & 147 & Wang et al., 1988 \\
\hline & Human milk & 169,181 & Ho and Baxter, 1997 \\
\hline \multirow[t]{10}{*}{ IGFBP-3 } & Plasmin & $95,97,149,150,151$ & Lalou et al., 1997 \\
\hline & & $155,160,198,220$ & Booth et al., 1996 \\
\hline & PSA & $97,132,159,173,179$ & Fielder et al., 1994 \\
\hline & Human serum & $97,148,149,150,154$ & Booth et al., 1996 \\
\hline & MMP-1 & 99 & Fowlkes et al., 1994 \\
\hline & MMP-2 (human fibroblasts) & 99 & Fowlkes et al., 1994 \\
\hline & MMP-3 & $99,109,176$ & Fowlkes et al., 1994 \\
\hline & Cathepsin D & $98,159,163,200$ & Claussen et al., 1997 \\
\hline & Thrombin & 97,206 & Booth et al., 1996 \\
\hline & MCF-7 cell line & 97 & Salahifar et al., 2000 \\
\hline \multirow[t]{4}{*}{ IGFBP-4 } & Rat neuronal cells & $90,120,132$ & Chernausek et al., 1995 \\
\hline & Human fibroblasts & 135 & Conover et al., 1995 \\
\hline & Cathepsin D & 135 & Claussen et al., 1997 \\
\hline & Calpain (human erythrocytes) & $3,86,122,138$ & This work \\
\hline \multirow[t]{6}{*}{ IGFBP-5 } & Human osteoblasts & 169 & Andress, 1995 \\
\hline & Porcine aortic smooth muscle cells & 137,138 & Imai et al., 1997 \\
\hline & Thrombin & $120,156,192$ & Zwad et al., 2002 \\
\hline & PAPP-A & 143,144 & Laursen et al., 2001 \\
\hline & Calpain (human erythrocytes) & $2,140,151$ & This work \\
\hline & Asp-N & 94,134 & Kalus et al., 1998 \\
\hline
\end{tabular}


Table 2 Calpain cleavage sequences.

\begin{tabular}{lcc}
\hline Protein & \multicolumn{2}{c}{ Cleavage } \\
\cline { 2 - 3 } & Site & Sequence \\
\hline IGFBP-4 (this work) & 2 & GDEAIH \\
& 86 & EIEAIQ \\
& 122 & KHFAKI \\
IGFBP-5 (this work) & 138 & KVNGAP \\
& 2 & SLGSFV \\
Crystallin (Shih et al., 1998) & 141 & KLTQSK \\
$\beta B 1$ & 152 & ENTAHP \\
& & \\
$\beta A 3$ & 12 & ATAAVN \\
& 15 & GPPPGP \\
$\beta B 2$ & 11 & ELESLP \\
$\beta B 3$ & 17 & TTKMAQ \\
& 8 & QTQAGK \\
Calpain (autolysis; & 5 & EQHSTP \\
Brown and Crawford, 1993) & 10 & PEQAAA \\
\hline
\end{tabular}

Cleavage occurs after the third residue of the cleavage sequence.

sequence (Fischer et al., 1986; Harris et al., 1988; Croall et al., 1996; Stabach et al., 1997). For example, 9 of the 11 calpain cleavages in the $\alpha$-tropomyosin polypeptide are in the $\mathrm{COOH}$-terminal half of the molecule (Goll et al., 2003) where the $\mathrm{COOH}$-terminal half of the helix is significantly less stable than the $\mathrm{NH}_{2}$-terminal half, suggesting that subsite specificity of the calpains depends on the conformation of the polypeptide, with a more open structure favoring cleavage.

Our present study has not revealed clear preferences for amino acid sequences, although in many cases a hydrophobic residue is present in the $\mathrm{P}_{2}$ position (Table 2 and Figure 7). For completeness, we also include in Table 2 two reports not covered by the reviews (Croall and Demartino, 1991; Goll et al., 2003). These data pertain to the $\mathrm{m}$-calpain cleavage of $\mathrm{N}$-terminal propeptides of $\beta$-crystallin, which are highly mobile and in random coil conformations (PDB: 1E7N; Clout et al., 2000).

In conclusion, we propose that calpains seem not to recognize amino acid sequences in target proteins, but cleave with low sequence specificity at unstructured or solvent-exposed fragments that connect folded, stable domains of target proteins, suggesting that calpains may modulate the functions of substrate proteins by cutting their interdomain regions.

\section{Materials and methods}

\section{Chemicals, plasmid, expression host strain and growth media}

Unless otherwise specified, all reagents were obtained from Sigma (Taufkirchen, Germany). Luria broth, agar, and antibiotics were purchased from Sigma-Aldrich. BL21 (DE 3) E. coli protein expression strains bought from Invitrogen (Karlsruhe, Germany) are designed for high-level protein expression using T7 RNA polymerase-based expression systems. pET 28a expression vector, based on the T7 promoter-driven system, was obtained from Novagen (Darmstadt, Germany). The restriction enzymes $\mathrm{Ndel}$ and BamHI were from New England Biolabs (Frankfurt,
Germany). Pfu polymerase and DNA ligase were purchased from Stratagene (La Jolla, USA). Antibodies and isopropyl $\beta$-D-thiogalactoside (IPTG) were obtained from Santa Cruz Biotechnology (Santa Cruz, USA) and Peq Labs (Erlangen, Germany), respectively. Plasmid miniprep kit and Ni-NTA resin were bought from Qiagen (Hilden, Germany). The nitrocellulose membranes, polyvinylidene fluoride (PVDF) membranes and the ion exchange and size exclusion chromatography columns were purchased from Amersham Pharmacia Biotech (Freiburg, Germany). Bradford reagent was from Bio-Rad (Munich, Germany). The ultrafiltration membranes used were from Amicon (Schwalbach, Germany).

\section{Cloning and protein expression}

Human recombinant IGFBP-5 protein was a generous gift from Roche Diagnostics (Penzberg, Germany). The IGFBP-4 cDNA was also obtained from Roche Diagnostics in BP4-2/pFDX500 vector. To purify the protein as a His-tag fusion protein, the IGFBP-4 cDNA (full-length residues 1-237) was subcloned into pET-28 (a) vector (Qiagen) with restriction sites at Ndel and $\mathrm{BamHI}$ in frame to a His-tag. Standard procedures were adopted for the construction of the vector pET-28 (a) with the desired insert (full-length IGFBP-4) which was expressed as a fusion protein in E. coli strain BL21 (DE 3) under kanamycin selection. The encoded amino acid sequences were gsshhhhhhssglvprgsMDEAIH...LADSFRE [the protein of interest is shown in capital letters and the amino acids of the His-tag and thrombin cleavage site (underlined) are in italics]. Expression was carried out in shaking cultures at $300 \mathrm{rpm}$ and $37^{\circ} \mathrm{C}$. The cultures were induced with $1 \mathrm{mM}$ IPTG at a cell density of $\mathrm{OD}_{600}=0.85$. Cells were harvested by centrifugation after $3 \mathrm{~h}$ of induction.

\section{Protein purification}

The cell pellets were resuspended in lysis buffer and kept for $1 \mathrm{~h}$ shaking. To obtain complete lysis, the cells were sonicated using a macro tip, with which pulsed, high-frequency sound waves are used to agitate and lyse cells. To prevent excessive heating, ultrasonic treatment was applied in multiple short bursts to the sample immersed in an ice bath. The sonication was carried out for 2 min at a duty cycle of $50 \%$ and output control 7 . The sonication/lysozyme treatment was carried out by first treating the cells with the lysozyme and then sonicating the extract. All of the extracts were clarified by centrifugation for $60 \mathrm{~min}$ at $60000 \mathrm{~g}$ at $4^{\circ} \mathrm{C}$. The supernatants were recovered and then analyzed for total protein by the Bradford protein assay. The supernatant was loaded onto a Ni-NTA column and protein elution was carried out using a pH gradient method (Qiagen). The fractions containing IGFBP- 4 were pooled and $\beta$-mercaptoethanol was added at a concentration of $10 \mathrm{~mm}$. The final volume was concentrated to approximately $2 \mathrm{ml}$ by ultrafiltration and then dialyzed against $6 \mathrm{~m}$ guanidinium chloride. The protein solution was then diluted into refolding buffer (Kalus et al., 1998). After $24 \mathrm{~h}$ of refolding at $4^{\circ} \mathrm{C}$, the protein solution was again concentrated by ultrafiltration and dialyzed against phosphate buffer and loaded onto an anion exchange column (Mono S) in which the proteins were bound to the column material in $25 \mathrm{~mm}$ phosphate buffer, $25 \mathrm{mM} \mathrm{NaCl}, \mathrm{pH} 7.2$, and bound proteins were fractionated by a linear gradient of $25-700 \mathrm{~mm} \mathrm{NaCl}$ over 20 column volumes. The fractions containing the protein were pooled and size exclusion chromatography was carried out on a Superdex 75 column.

\section{$\mu$-Calpain storage conditions}

$\mu$-Calpain was isolated from human erythrocytes as described previously (Gabrijelcic-Geiger et al., 2001). The purified enzyme 
was dialyzed against $10 \mathrm{~mm}$ Tris, $150 \mathrm{~mm} \mathrm{NaCl}, 1 \mathrm{~mm}$ EDTA, $0.2 \mathrm{~mm}$ phenylmethylsulfonyl fluoride (calpain storage buffer) and stored at $4^{\circ} \mathrm{C}$ until use. On the day of use, a small aliquot was taken and reactivated with $14 \mathrm{~mm} \beta$-mercaptoethanol prior to the proteolysis assays.

\section{IGFBP-4 and IGFBP-5 limited proteolysis assays}

Purified IGFBP-4 and IGFBP-5 were incubated separately with calpain at a molar ratio of 1:50 in calpain assay buffer $(25 \mathrm{~mm}$ Tris, $150 \mathrm{~mm} \mathrm{NaCl}, \mathrm{pH}$ 7.3) supplemented with $\mathrm{CaCl}_{2}$ and kept for different time intervals at room temperature. Addition of $10 \mathrm{~mm}$ EDTA stopped the reactions. The fragments were separated by SDS-PAGE and visualized by Coomassie Blue staining.

\section{Calpastatin inhibitory and protein stability assays}

Domain 1 of calpastatin was added in equimolar ratio to calpain. Purified IGFBP-4 and IGFBP-5 were incubated separately with calpain and calpastatin at the molar ratio of 1:50:1 (protein/calpain/calpastatin) in calpain assay buffer supplemented with $\mathrm{CaCl}_{2}$ to a final concentration of $1 \mathrm{~mm}$ and kept for different time intervals at room temperature. Addition of $10 \mathrm{mM}$ EDTA and SDS-PAGE loading buffer stopped the reaction. Subsequently, the protein fragments were separated by SDS-PAGE and visualized by Coomassie blue staining. To ensure that the respective proteins were not degrading autocatalytically and that the degradation was due to calpain cleavage, we carried out a stability test by keeping the proteins at room temperature in calpain assay buffer without adding calpain, and taking aliquots for SDS-PAGE at different time intervals for up to 3 days; no degradation was observed, even after 3 days.

\section{Electrophoresis and Western blot analysis}

Aliquots of the protein samples treated with calpain were resolved on $12 \%$ SDS-PAGE, which was carried out using the Laemmli procedure. Western blot analysis was then carried out using primary antibodies against the protein. Alkaline phosphatase-conjugated secondary antibodies were then used against the primary antibody and the membrane was further developed by incubation with 5-bromo-4-chloro-3-indolyl phosphate (BCIP)/nitroblue tetrazolium (NBT) alkaline phosphatase substrate for 15-30 min.

\section{$\mathrm{N}$-Terminal sequencing of the protein fragments using PVDF membranes, reversed-phase HPLC and mass spectrometry}

The reaction mixtures once resolved on SDS-PAGE were used to electroblot the protein fragments onto a PVDF membrane using the standard procedure described by Sambrook et al. (1989) so that the $\mathrm{NH}_{2}$-terminal amino acids of the intact and cleaved products could be sequenced. The electroblot was carried out using semi-dry electroblotting apparatus at constant power supply of $110 \mathrm{mV}$ for $1 \mathrm{~h}$. The protein fragment-blotted PVDF membrane was stained with Coomassie blue dye. Coomassie-stained bands were cut from the membrane and used for $\mathrm{N}$-terminal sequencing by Edman degradation. The results obtained from the sequence analysis were then mapped on the IGFBP sequences (Swiss-Prot, primary accession number P22692 for IGFBP-4 and P24593 for IGFBP-5). To further confirm the results of $\mathrm{N}$-terminal sequencing, the reaction mixtures were purified by reverse-phase HPLC, sequenced and analyzed by mass spectrometry using MALDI-MS.

\section{NMR spectroscopy}

Standard 1D proton spectra were acquired on a Bruker DRX 600 spectrometer at $300 \mathrm{~K}$. The protein samples were typically 0.3-0.6 mM in phosphate-buffered saline (PBS).

\section{Acknowledgments}

This work was supported by grants (SFB 469) from the Deutsche Forschungsgemeinschaft (DFG). We thank Dusica GabrijelcicGeiger and Barbara Meisel for the isolation of calpain.

\section{References}

Andress, D.L. (1995). Heparin modulates the binding of insulinlike growth-factor (Igf) binding protein-5 to a membrane-protein in osteoblastic cells. J. Biol. Chem. 270, 28289-28296.

Baxter, R.C. (2000). Insulin-like growth factor (IGF)-binding proteins: interactions with IGFs and intrinsic bioactivities. Am. J. Physiol. Endocrinol. Metab. 278, E967-E976.

Binoux, M., Lalou, C., and Mahseni, S. (1999). In: The IGF System. Molecular Biology, Physiology, and Clinical Applications, R.G. Rosenfeld and C.T. Roberts, eds. (Totowa, NJ, USA: Humana Press), pp. 281-313.

Booth, B.A., Boes, M., and Bar, R.S. (1996). IGFBP-3 proteolysis by plasmin, thrombin, serum: heparin binding, IGF binding, and structure of fragments. Am. J. Physiol. Endocrinol. Metab. 34, E465-E470.

Brown, N. and Crawford, C. (1993). Structural modifications associated with the change in $\mathrm{Ca}^{2+}$ sensitivity on activation of m-calpain. FEBS Lett. 322, 65-68.

Bunn, R.C. and Fowlkes, J.L. (2003). Insulin-like growth factor binding protein proteolysis. Trends Endocrinol. Metab. 14, 176-181.

Chernausek, S.D., Smith, C.E., Duffin, K.L., Busby, W.H., Wright, G., and Clemmons, D.R. (1995). Proteolytic cleavage of insulin-like growth-factor binding-protein-4 (Igfbp-4) - localization of cleavage site to nonhomologous region of native Igfbp-4. J. Biol. Chem. 270, 11377-11382.

Claussen, M., Kubler, B., Wendland, M., Neifer, K., Schmidt, B., Zapf, J., and Braulke, T. (1997). Proteolysis of insulin-like growth factors (IGF) and IGF binding proteins by cathepsin D. Endocrinology 138, 3797-3803.

Clemmons, D.R. (2001). Use of mutagenesis to probe IGF-binding protein structure/function relationships. Endocr. Rev. 22, 800-817.

Clout, N.J., Basak, A., Wieligmann, K., Bateman, O.A., Jaenicke, R., and Slingsby, C. (2000). The N-terminal domain of $\beta$ B2crystallin resembles the putative ancestral homodimer. $\mathrm{J}$. Mol. Biol. 304, 253-257.

Conover, C.A., Durham, S.K., Zapf, J., Masiarz, F.R., and Kiefer, M.C. (1995). Cleavage analysis of insulin-like growth-factor (Igf)-dependent Igf-binding protein-4 proteolysis and expression of protease-resistant Igf-binding protein-4 mutants. J. Biol. Chem. 270, 4395-4400.

Croall, D.E. and Demartino, G.N. (1991). Calcium-activated neutral protease (calpain) system - structure, function, and regulation. Physiol. Rev. 71, 813-847.

Croall, D.E., Chacko, S., and Wang, Z. (1996). Cleavage of caldesmon and calponin by calpain: substrate recognition is not dependent on calmodulin binding domains. Biochim. Biophys. Acta 1298, 276-284.

Dear, T.N. and Boehm, T. (2001). Identification and characterization of two novel calpain large subunit genes. Gene 274, 245-252.

Fielder, P.J., Rosenfeld, R.G., Graves, H.C.B., Grandbois, K., Maack, C.A., Sawamura, S., Ogawa, Y., Sommer, A., and Cohen, P. (1994). Biochemical-analysis of prostate-specific 
antigen-proteolyzed insulin-like growth-factor binding protein-3. Growth Regul. 4, 164-172.

Firth, S.M. and Baxter, R.C. (2002). Cellular actions of the insulinlike growth factor binding proteins. Endocr. Rev. 23, 824-854.

Fischer, S., Vandekerckhove, J., Ampe, C., Traub, P., and Weber, K. (1986). Protein-chemical identification of the major cleavage sites of the $\mathrm{Ca} 2$ proteinase on murine vimentin, the mesenchymal intermediate filament protein. Biol. Chem. Hoppe-Seyler 367, 1147-1152.

Fowlkes, J.L., Enghild, J.J., Suzuki, K., and Nagase, H. (1994). Matrix metalloproteinases degrade insulin-like growth factorbinding protein-3 in dermal fibroblast-cultures. J. Biol. Chem. 269, 25742-25746.

Gabrijelcic-Geiger, D., Mentele, R., Meisel, B., Hinz, H., AssfalgMachleidt, L., Machleidt, W., Moller, A., and Auerswald, E.A. (2001). Human m-calpain: simple isolation from erythrocytes and characterization of autolysis fragments. Biol. Chem. 382, 1733-1737.

Glading, A., Uberall, F., Keyse, S.M., Lauffenburger, D.A., and Wells, A. (2001). Membrane proximal ERK signaling is required for $\mathrm{m}$-calpain activation downstream of epidermal growth factor receptor signaling. J. Biol. Chem. 276, 23341-23348.

Glading, A., Lauffenburger, D.A., and Wells, A. (2002). Cutting to the chase: calpain proteases in cell motility. Trends Cell Biol. $12,46-54$.

Goll, D.E., Thompson, V.F., Li, H.Q., Wei, W., and Cong, J.Y. (2003). The calpain system. Physiol. Rev. 83, 731-801.

Harris, A.S., Croall, D.E., and Morrow, J.S. (1988). The calmodulin-binding site in a-fodrin is near the calcium-dependent protease-I cleavage site. J. Biol. Chem. 263, 15754-15761.

Ho, P.J. and Baxter, R.C. (1997). Characterization of truncated insulin-like growth factor-binding protein-2 in human milk. Endocrinology 138, 3811-3818.

Huang, Y. and Wang, K.K. (2001). The calpain family and human disease. Trends Mol. Med. 7, 355-362.

Imai, Y., Busby, W.H., Smith, C.E., Clarke, J.B., Garmong, A.J., Horwitz, G.D., Rees, C., and Clemmons, D.R. (1997). Protease-resistant form of insulin-like growth factor-binding protein 5 is an inhibitor of insulin-like growth factor-l actions on porcine smooth muscle cells in culture. J. Clin. Invest. 100, 2596-2605.

Jaques, G., Noll, K., Wegmann, B., Witten, S., Kogan, E., Radulescu, R.T., and Havemann, K. (1997). Nuclear localization of insulin-like growth factor binding protein 3 in a lung cancer cell line. Endocrinology 138, 1767-1770.

Kalus, W., Zweckstetter, M., Renner, C., Sanchez, Y., Georgescu, J., Grol, M., Demuth, D., Schumacher, R., Dony, C., Lang, K., et al. (1998). Structure of the IGF-binding domain of the insulin-like growth factor-binding protein-5 (IGFBP-5): implications for IGF and IGF-I receptor interactions. EMBO J. 17, 6558-6572.

Khandwala, H.M., McCutcheon, I.E., Flyvbjerg, A., and Friend, K.E. (2000). The effects of insulin-like growth factors on tumorigenesis and neoplastic growth. Endocr. Rev. 21, 215-244.

Khorchid, A. and Ikura, M. (2002). How calpain is activated by calcium. Nat. Struct. Biol. 9, 239-241.

Kumamoto, T., Kleese, W.C., Cong, J., Goll, D.E., Pierce, P.R., and Allen, R.E. (1992). Localization of the $\mathrm{Ca}^{2+}$-dependent proteinases and their inhibitor in normal, fasted, and denervated rat skeletal-muscle. Nat. Struct. Biol. 232, 60-77.

Kuwaki, T., Satoh, H., Ono, T., Shibayama, F., Yamashita, T., and Nishimura, T. (1989). Nilvadipine attenuates ischemic degradation of gerbil brain cytoskeletal proteins. Stroke 20, 78-83.

Lalou, C., Sawamura, S., Segovia, B., Ogawa, Y., and Binoux, M. (1997). Proteolytic fragments of insulin-like growth factor binding protein-3: $\mathrm{N}$-terminal sequences and relationships between structure and biological activity. C. R. Acad. Sci. Ser. III 320, 621-628.
Laursen, L.S., Overgaard, M.T., Soe, R., Boldt, H.B., SottrupJensen, L., Giudice, L.C., Conover, C.A., and Oxvig, C. (2001). Pregnancy-associated plasma protein-A (PAPP-A) cleaves insulin-like growth factor binding protein (IGFBP)-5 independent of IGF: implications for the mechanism of IGFBP-4 proteolysis by PAPP-A. FEBS Lett. 504, 36-40.

$\mathrm{Li}, \mathrm{H}$., Thompson, V.F., and Goll, D.E. (2002). Effects of autolysis and properties of $\mu$ - and m-calpain. Mol. Biol. Cell. 13, 304A-304A.

Manes, S., Mira, E., Barbacid, M.D., Cipres, A., Fernandez Resa, P., Buesa, J.M., Merida, I., Aracil, M., Marquez, G., and Martinez, C. (1997). Identification of insulin-like growth factorbinding protein-1 as a potential physiological substrate for human stromelysin-3. J. Biol. Chem. 272, 25706-25712.

Mellgren, R.L. (1997). Evidence for participation of a calpain-like cysteine protease in cell cycle progression through late $\mathrm{G}(1)$ phase. Biochem. Biophys. Res. Commun. 236, 555-558.

Moldoveanu, T., Hosfield, C.M., Lim, D., Elce, J.S., Jia, Z.C., and Davies, P.L. (2002). A Ca' ${ }^{+}$switch aligns the active site of calpain. Cell 108, 649-660.

Moldoveanu, T., Jia, Z.C., and Davies, P.L. (2004). Calpain activation by cooperative $\mathrm{Ca}^{2+}$ binding at two non-EF-hand sites. J. Biol. Chem. 279, 6106-6114.

Nishihara, H., Nakagawa, Y., Ishikawa, H., Ohba, M., Shimizu, K., and Nakamura, T. (2001). Matrix vesicles and media vesicles as nonclassical pathways for the secretion of $\mathrm{m}$-calpain from MC3T3-E1 cells. Biochem. Biophys. Res. Commun. 285, 845-853.

Oh, Y. and Rosenfeld, R.G. (1999). IGF-independent actions of the IGF-binding proteins. In: The IGF System. Molecular Biology, Physiology, and Clinical Applications, R.G. Rosenfeld and C.T. Roberts, eds. (Totowa, NJ, USA: Humana Press).

Pal, G.P., De Veyra, T., Elce, J.S., and Jia, Z.C. (2003). Crystal structure of a mu-like calpain reveals a partially activated conformation with low $\mathrm{Ca}^{2+}$ requirement. Structure 11, 1521-1526.

Payet, L.D., Wang, X.H., Baxter, R.C., and Firth, S.M. (2003). Amino- and carboxyl-terminal fragments of insulin-like growth factor (IGF) binding protein-3 cooperate to bind IGFs with high affinity and inhibit IGF receptor interactions. Endocrinology 144, 2797-2806.

Rehm, T., Huber, R., and Holak, T.A. (2002). Application of NMR in structural proteomics: screening for proteins amenable to structural analysis. Structure 10, 1613-1618.

Salahifar, H., Firth, S.M., Baxter, R.C., and Martin, J.L. (2000). Characterization of an amino-terminal fragment of insulin like growth factor binding protein 3 and its effects in MCF-7 breast cancer cells. Growth Horm. IGF Res. 10, 367-377.

Sambrook, J., Fritsch, E.F., and Maniatis, T. (1989). Molecular Cloning; a Laboratory Manual, 2nd Edition (Cold Spring Harbor, USA: Cold Spring Harbor Laboratory Press).

Sasaki, T., Kikuchi, T., Yumoto, N., Yoshimura, N., and Murachi, T. (1984). Comparative specificity and kinetic studies on porcine calpain-I and calpain-II with naturally occurring peptides and synthetic fluorogenic substrates. J. Biol. Chem. 259, 2489-2494.

Sato, K. and Kawashima, S. (2001). Calpain function in the modulation of signal transduction molecules. Biol. Chem. 382, 743-751.

Schedlich, L.J., Young, T.F., Firth, S.M., and Baxter, R.C. (1998). Insulin-like growth factor-binding protein (IGFBP)-3 and IGFBP-5 share a common nuclear transport pathway in T47D human breast carcinoma cells. J. Biol. Chem. 273, 18347-18352.

Shand, J.H., Beattie, J., Song, H., Phillips, K., Kelly, S.M., Flint, D.J., and Allan, G.J. (2003). Specific amino acid substitutions determine the differential contribution of the $\mathrm{N}$ - and C-terminal domains of insulin-like growth factor (IGF)-binding protein-5 in binding IGF-I. J. Biol. Chem. 278, 17859-17866.

Shih, M., Lampi, K., Shearer, T., and David, L. (1998). Cleavage of b-crystallins during maturation of bovine lens. Mol. Vis. 4 , 4. 
Sorimachi, H. and Suzuki, K. (2001). The structure of calpain. J. Biochem. 129, 653-664.

Stabach, P.R., Cianci, C.D., Glantz, S.B., Zhang, Z.S., and Morrow, J.S. (1997). Site-directed mutagenesis of all spectrin at codon 1175 modulates its mu-calpain susceptibility. Biochemistry 36, 57-65.

Strobl, S., Fernandez-Catalan, C., Braun, M., Huber, R., Masumoto, H., Nakagawa, K., Irie, A., Sorimachi, H., Bourenkow, G., Bartunik, H. et al. (2000). The crystal structure of calciumfree human m-calpain suggests an electrostatic switch mechanism for activation by calcium. Proc. Natl. Acad. Sci. USA 97, 588-592.

Tompa, P. and Friedrich, P. (2000). Kinetic analysis of human mucalpain autolysis. In: Calpain Methods and Protocols, J.S. Elce, ed. (Totowa, NJ, USA: Humana Press), pp. 129-136.

Wang, J.F., Hampton, B., Mehlman, T., Burgess, W.H., and Rechler, M.M. (1988). Isolation of a biologically active fragment from the carboxy terminus of the fetal rat binding-protein for insulin-like growth factors. Biochem. Biophys. Res. Commun. 157, 718-726.

Weber, T., Baumgartner, R., Renner, C., Marahiel, M.A., and Holak, T.A. (2000). Solution structure of PCP, a prototype for the peptidyl carrier domains of modular peptide synthetases. Struct. Fold. Des. 8, 407-418.

Wraight, C.J., Liepe, I.J., White, P.J., Hibbs, A.R., and Werther, G.A. (1998). Intranuclear localization of insulin-like growth factor binding protein-3 (IGFBP-3) during cell division in human keratinocytes. J. Invest. Dermatol. 111, 239-242.

Zeslawski, W., Beisel, H.G., Kamionka, M., Kalus, W., Engh, R.A., Huber, R., Lang, K., and Holak, T.A. (2001). The interaction of insulin-like growth factor-I with the $\mathrm{N}$-terminal domain of IGFBP-5. EMBO J. 20, 3638-3644.

Zheng, B., Clarke, J.B., Busby, W.H., Duan, C.M., and Clemmons, D.R. (1998). Insulin-like growth factor-binding protein5 is cleaved by physiological concentrations of thrombin. Endocrinology 139, 1708-1714.

Zwad, O., Kubler, B., Roth, W., Scharf, J.G., Saftig, P., Peters, C., and Braulke, T. (2002). Decreased intracellular degradation of insulin-like growth factor binding protein-3 in cathepsin L-deficient fibroblasts. FEBS Lett. 510, 211-215.

Received August 26, 2004; accepted November 26, 2004 